Short communication

\title{
Rumen and liver measurements of lambs fed with high inclusions of crude glycerin in adaptation and finishing period of feedlot
}

\author{
Marco T.C. Almeida*, Jane M.B. Ezequiel, Josimari R. Paschoaloto, Henrique L. Perez, \\ Vanessa B. Carvalho, Edivilson S. Castro Filho, Eric H.C.B. van Cleef \\ Department of Animal Science, São Paulo State University (Unesp), School of Agricultural and Veterinarian Sciences, 14884-900, Jaboticabal, São Paulo, Brazil
}

A R T I C L E IN F O

\section{Keywords:}

By-product

Glycerol

Papillae

Sheep

\begin{abstract}
A B S T R A C T
Crude glycerin is the main by-product of biodiesel industry and has great potential for reducing the feed costs in ruminant feedlot systems without affecting animal health and performance, mainly as a replacement for corn grain. The objective of this study was to evaluate the effects of increasing inclusions of crude glycerin (up to $30 \%$ ) in diets for crossbred feedlot lambs in two different periods (adaptation and finishing) on the rumen morphometric and liver variables. Fifty-five 3-month-old crossbred lambs were randomly allocated in individual pens indoors, assigned to a complete randomized block design and fed with four experimental diets, containing $0,10,20$ or $30 \%$ crude glycerin. Three animals were slaughtered at the end of the pre-adaptation period (d0), twelve at the end of the adaptation period (d14), and the remaining $(n=40)$ when they reached approximately $35 \mathrm{~kg}$ BW. After slaughtered, the stomach compartments and liver were collected and evaluated. All stomach compartments, number of rumen papillae and mitotic index were higher for the finishing period $(P<0.05)$. Crude glycerin treatments showed greater rumen weights when compared to control treatment (G0 vs G, $\mathrm{P}=0.01$ ) in the finishing period. The increasing inclusion of up to $30 \%$ of crude glycerin $/ \mathrm{kg} \mathrm{DM}$ in diets for crossbred lambs did not compromise the stomach compartments and rumen papillae measurements in both periods of the feedlot. No clinical manifestations resulted from ruminal acidosis (such as liver abscess, ruminitis, and lesions in the ruminal mucosa) were observed in any period and treatment studied. Thus, we conclude that the replacement of corn cracked grain by crude glycerin (up to $30 \% \mathrm{DM}$ ) was effective in the animals' adaptation to concentrate-based diets.
\end{abstract}

\section{Introduction}

Abrupt changes in diets, as well as the high inclusion of starch-rich cereal grains, adversely affects the animal performance in the two first weeks of the feedlot, mainly due to ruminal acidosis (Nagaraja and Titgemeyer, 2007; McCann et al., 2016). Changes in feeding behavior with reduced feed intake (Missio et al., 2010) and clinical manifestations such as laminitis, liver abscesses, ruminitis, and inappropriate ruminal fermentation (Dirksen, 1985; Resende Junior et al., 2006) are prevalent when animals are adapted for less than 14 days, or when they do not receive a correct adaptation to the diets (Brown et al., 2006).

The rumen epithelium has several physiological functions, such as the absorption and metabolism of nutrients and microbial by-products (volatile fatty acids). The rumen papillae increase the surface area for the absorption and microbial attachment to the rumen wall, playing a significant role in animals' feed intake and weight gain (Galfi et al., 1991; Kern et al., 2016). Although concentrate-rich diets may stimulate the development of ruminal papillae more than roughage-rich diets (Stobo et al., 1966), lesions in the papillae caused by acidosis may compromise the animal performance.

Crude glycerin has been evaluated as a macro-ingredient, and it is considered safe for use as animal feed (FDA, 2006, 21 C.F.R.582.1320), with potential to reduce feed costs in ruminant production systems, without causing negative effects on animal performance, when replaces corn grain (Ezequiel et al., 2015; van Cleef et al., 2015; Almeida et al., 2017). This by-product can prevent metabolic disorders, avoiding severe reduction of the ruminal $\mathrm{pH}$ and the development of rumen acidosis, due to its fermentation profile (Polizel et al., 2013; Favaro et al., 2015). The larger portion of crude glycerin ( $\sim 43 \%)$ is rapidly absorbed by rumen papillae, whereas $25-45 \%$ are fermented to butyrate and propionate by alternative fermentative pathway (via succinate), and do not generate lactic acid, benefiting the rumen development and improving the feed efficiency (Krehbiel, 2008; Omazic et al., 2015).

\footnotetext{
* Corresponding author.

E-mail address: marcotulio695@yahoo.com.br (M.T.C. Almeida).
} 
However, the adequate levels of crude glycerin in the adaptation period and the consequences for the finishing period are still unknown. We hypothesized that crude glycerin could provide an alternative to totally replace corn grain, without affecting animal health. Thus, the objective of this study was to evaluate the effects of increasing inclusions of crude glycerin (up to 30\%, DM basis) in diets for crossbred feedlot lambs in two different periods (adaptation and finishing), on the rumen morphometric and liver variables.

\section{Materials and methods}

The Institutional Animal Care and Use Committee of the São Paulo State University approved all experimental protocols adopted in the current study (approval number: 06329/14).

The present study was carried out at the Animal Unit of Digestive and Metabolic Studies in the Department of Animal Science from São Paulo State University, Jaboticabal campus, Brazil. Fifty-five 3-monthold crossbred (Santa Inês $\times$ Dorper) male lambs $(17.8 \pm 0.9 \mathrm{~kg} \mathrm{BW})$ were randomly allocated in individual pens $\left(1.2 \mathrm{~m}^{2}\right)$ indoors and assigned to a complete randomized block design (by initial BW). The experimental design was four levels of crude glycerin treatments by three-time periods of feedlot (pre-adaptation, adaptation, and finishing). The treatments were: G0 (control treatment, without crude glycerin), G10 (10\% of crude glycerin, DM basis), G20 (20\% of crude glycerin, DM basis) and G30 (30\% of crude glycerin, DM basis).

Within $24 \mathrm{~h}$ of arrival, the animals were vaccinated and dewormed. During the seven subsequent days, animals were submitted to a preadaptation period, when they were fed ad libitum a standard foragebased diet, composed of corn silage (95\%), soybean hulls, soybean meal, urea and minerals (Table 1). This period was crucial to standardize the animal feeding and ruminal microflora before starting the experimental period. After pre-adaptation period three random lambs were slaughtered $(\mathrm{d} 0)$ to serve as the initial baseline for comparisons with the future results. The remaining animals $(n=52,17.9 \pm 0.5 \mathrm{~kg}$ $\mathrm{BW}$ ) were fed with four experimental diets containing increasing inclusions of crude glycerin for a 14-d adaptation period. It was used three step-up diets (four days to diet 1; five days to diet 2 and five days to diet 3) containing increasing levels of concentrate (diet $1=20 \%$, diet $2=40 \%$ and finishing diet $=60 \%$, Table 1 ).

After the adaptation period (d14), three lambs from each treatment $(n=12)$ were randomly selected and slaughtered to evaluate the effect of crude glycerin during this period. The remaining animals $(n=40$, $21.7 \pm 2.7 \mathrm{~kg} \mathrm{BW}$ ) continued being fed their respective experimental diets until reached approximately $35 \mathrm{~kg}$ BW, and then they were harvested. The total period of trial lasted, on average, $59 \mathrm{~d}$.

Experimental diets were formulated to be isonitrogenous (\% CP) and isocaloric (Mcal $/ \mathrm{kg} \mathrm{EM}$ ), according to recommendations of NRC (2007), and were offered to the lambs ad libitum. Diets were composed of corn silage (roughage source), and corn cracked grain, soybean hulls, soybean meal, urea, crude glycerin (except the control diet), mineralvitamin premix, limestone, and dicalcium phosphate, as concentrate. The crude glycerin was obtained from a commercial soybean oil and meal production plant. Lambs were fed twice daily (0800 and $1600 \mathrm{~h})$ and had ad libitum access to water. The concentrate and corn silage were weighed separately daily and mixed with crude glycerin at the moment of feed delivery, feeding animals $50 \%$ of total mixed ration in each meal.

Three animals were randomly selected and slaughtered at the end of pre-adaptation period ( $\mathrm{d} 0$ ), twelve at the end of adaptation period (d14), and the remaining ones $(n=40)$ when they reached approximately $35 \mathrm{~kg}$ BW. All the animals were subjected to a 16-h fasting period and body weights were recorded to determine the shrunk final BW. The lambs were stunned by brain concussion, using a non-penetrating bolt pistol. Bleeding was performed by severing the carotid arteries and jugular veins immediately after stunning. After evisceration, rumen, reticulum, omasum and abomasum were emptied, washed and weighed. The rumen received a score according to the incidence of lesions using a scale of 0 (no lesions noted) to 10 (severe lesions and abnormalities), as described by Bigham and McManus (1975). At slaughter, each liver was examined and scored regarding of the size and number of abscesses ( $\mathrm{A}-=1, \mathrm{~A}=2$ and $\mathrm{A}+=3$ ), according to Brink et al. (1990). Edible livers without abnormality were labeled as normal

Table 1

Ingredients and chemical composition of experimental diets.

\begin{tabular}{|c|c|c|c|c|c|c|c|c|c|c|c|c|c|}
\hline \multirow[t]{2}{*}{ Item } & \multirow[t]{2}{*}{ Pre-adapt diet } & \multicolumn{4}{|c|}{ Adaptation diets $1^{\mathrm{a}}$} & \multicolumn{4}{|c|}{ Adaptation diets $2^{\mathrm{a}}$} & \multicolumn{4}{|c|}{ Finishing diets ${ }^{\mathrm{a}}$} \\
\hline & & G0 & G10 & G20 & G30 & G0 & G10 & G20 & G30 & G0 & G10 & G20 & G30 \\
\hline \multicolumn{14}{|l|}{ Ingredients (\% DM) } \\
\hline Corn silage & 95 & 80 & 80 & 80 & 80 & 60 & 60 & 60 & 60 & 40 & 40 & 40 & 40 \\
\hline Corn cracked grain & 0 & 15 & 10 & 5 & 0 & 30 & 20 & 10 & 0 & 30 & 20 & 10 & 0 \\
\hline Soybean hulls & 1.5 & 1.0 & 1.0 & 1.1 & 1.1 & 3.6 & 3.2 & 2.8 & 2.2 & 7.8 & 7.2 & 6.3 & 4.5 \\
\hline Soybean meal & 1.9 & 2.4 & 2.2 & 1.8 & 1.6 & 5.0 & 5.0 & 5.0 & 5.2 & 20.6 & 21.0 & 21.6 & 23.1 \\
\hline Urea & 0.5 & 0.7 & 0.9 & 1.1 & 1.3 & 0.4 & 0.7 & 1.0 & 1.3 & 0.6 & 0.9 & 1.1 & 1.3 \\
\hline Crude glycerin $^{\mathrm{b}}$ & 0.0 & 0.0 & 5.0 & 10.0 & 15.0 & 0.0 & 10.0 & 20.0 & 30.0 & 0.0 & 10.0 & 20.0 & 30.0 \\
\hline Mineral premix ${ }^{\mathrm{c}}$ & 0.5 & 0.5 & 0.5 & 0.5 & 0.5 & 0.5 & 0.5 & 0.4 & 0.4 & 0.5 & 0.5 & 0.5 & 0.5 \\
\hline Limestone & 0.4 & 0.3 & 0.3 & 0.3 & 0.3 & 0.4 & 0.3 & 0.4 & 0.4 & 0.5 & 0.5 & 0.5 & 0.5 \\
\hline Dicalcium phosphate & 0.2 & 0.1 & 0.2 & 0.3 & 0.3 & 0.2 & 0.3 & 0.4 & 0.4 & 0.0 & 0.0 & 0.0 & 0.2 \\
\hline \multicolumn{14}{|l|}{ Chemical composition } \\
\hline $\mathrm{DM}, \%$ & 33.4 & 42.2 & 42.3 & 42.5 & 42.6 & 53.9 & 54.2 & 54.5 & 54.8 & 65.8 & 66.1 & 66.4 & 66.6 \\
\hline $\mathrm{CP}, \% \mathrm{DM}$ & 9.4 & 10.3 & 10.3 & 10.3 & 10.3 & 10.9 & 10.9 & 10.9 & 10.9 & 17.7 & 17.7 & 17.7 & 17.7 \\
\hline ME, Mcal/kg DM ${ }^{\mathrm{d}}$ & 2.3 & 2.4 & 2.4 & 2.4 & 2.4 & 2.6 & 2.6 & 2.6 & 2.6 & 2.7 & 2.7 & 2.7 & 2.7 \\
\hline Starch, \% DM & 22.5 & 32.2 & 27.8 & 23.4 & 18.9 & 41.0 & 32.1 & 23.3 & 14.5 & 37.3 & 28.5 & 19.7 & 10.9 \\
\hline $\mathrm{EE}, \% \mathrm{DM}$ & 3.1 & 3.2 & 3.0 & 2.8 & 2.7 & 3.3 & 2.9 & 2.6 & 2.2 & 3.0 & 2.7 & 2.3 & 2.0 \\
\hline aNDF, \% DM ${ }^{\mathrm{e}}$ & 52.0 & 45.8 & 45.1 & 44.4 & 43.7 & 39.8 & 38.0 & 36.3 & 34.5 & 34.8 & 33.0 & 31.1 & 28.7 \\
\hline $\mathrm{ADF}, \% \mathrm{DM}$ & 33.5 & 28.7 & 28.5 & 28.3 & 28.1 & 24.1 & 23.5 & 22.9 & 22.2 & 19.2 & 18.5 & 17.7 & 16.5 \\
\hline Ca, \% DM & 0.5 & 0.5 & 0.5 & 0.5 & 0.5 & 0.5 & 0.5 & 0.5 & 0.5 & 0.5 & 0.5 & 0.5 & 0.5 \\
\hline $\mathrm{P}, \% \mathrm{DM}$ & 0.3 & 0.3 & 0.3 & 0.3 & 0.3 & 0.3 & 0.3 & 0.3 & 0.3 & 0.3 & 0.3 & 0.3 & 0.3 \\
\hline
\end{tabular}

a Experimental diets: G0, control diet; G10, inclusion of $10 \%$ crude glycerin; G20, inclusion of $20 \%$ crude glycerin; G30, inclusion of $30 \%$ crude glycerin.

b Composition per kg: glycerol (830 g), DM (950 g), CP (11 g), salts $(60 \mathrm{~g})$ and methanol $(<0.1 \mathrm{~g})$.

c Composition per kg: P (75 g), Ca (223 g), S (10 g), Zn (3 g), Na (60 g), Co (20 mg), I (40 mg), Se (24 mg), F (750 mg), Mg (5 g), Mn (1,8 g), Fe (402 mg), Vit A (312.500 UI), Vit D (50.000 UI), Vit E (437 UI).

d Metabolizable energy (Mcal/kg DM) was calculated using NRC (2007).

${ }^{\mathrm{e}} \mathrm{NDF}$ assayed using heat stable $\alpha$-amylase and expressed inclusive of residual ash. 
and received the grade 0 .

Two fragments $\left(1 \mathrm{~cm}^{2}\right)$ of each rumen were collected from the cranial region of the ventral sac. One fragment was immediately placed into a phosphate buffer solution $(0.1 \mathrm{M}, \mathrm{pH} 7.4)$ and cooled for macroscopic analysis. The other fraction was fixed with Bouin solution for $24 \mathrm{~h}$ and kept in alcohol solution $\left(70^{\circ}\right)$, until histological routine processing in paraffin (Daniel et al., 2006; Resende Junior et al., 2006).

The macroscopic morphological variables evaluated at rumen wall were: the number of papillae per $\mathrm{cm}^{2}$ of wall (NOP); average papillae area (APA); total absorptive surface area per $\mathrm{cm}^{2}$ of wall (ASA) and papillae area (PA), expressed as a percentage of ASA. The NOP was manually counted by 3 independent trained evaluators, and 10 papillae were randomly sectioned at the base of each fragment, scanned and the APA was measured using the UTHSCSA Image Tool software (The University of Texas - Health Science Center, San Antonio, TX, USA). The rumen wall ASA $\left(\mathrm{cm}^{2}\right)$ and PA (\% of ASA) were calculated as follows: $\mathrm{ASA}=1+(\mathrm{NOP} * \mathrm{APA})-(\mathrm{NOP} * 0.002)$ and $\mathrm{PA}=(\mathrm{NOP} * \mathrm{APA})$ $/($ ASA $) * 100$, where the number 1 represents the $1-\mathrm{cm}^{2}$ fragment collected and 0.002 is the estimated basal area of papillae.

The other fragment $\left(1 \mathrm{~cm}^{2}\right)$ was microscopically evaluated for the proportion of epithelial basal cells undergoing mitosis. Three separate papillae of each sample (animal) were stained with hematoxylin and eosin, embedded in paraffin wax and sectioned. The mitotic index (MI) was calculated by dividing the number of cells showing mitotic figures by the total number of nuclei on the epithelium basal layer.

Feed samples (pooled within treatment) of each experimental period (pre-adaptation, adaptation and finishing) were analyzed for dry matter (DM; method 930.15), crude protein (CP; method 988.05) and ether extract (EE; method 920.39), using standard procedures of AOAC (1990). Starch was analyzed according to Hendrix (1993). The neutral detergent fiber (NDF) and acid detergent fiber (ADF) contents were estimated according to Van Soest and Wine (1967), using a heat-stable $\alpha$-amylase, without sodium sulfite, and expressed inclusive of residual ash.

All data recorded were processed as a randomized complete block design with animals being blocked according to initial BW. Data were analyzed using the MIXED procedure of SAS (version 9.4), including the CONTRAST option. The models included the main effects of treatments (G0, G10, G20 and G30), periods (adaptation and finishing) and the treatment $\times$ period interaction (TR $\times$ PR). Within each period, orthogonal contrasts were used to assess the linear and quadratic effects of crude glycerin, as well as the contrast between control treatment and crude glycerin treatments (G0 vs G). The covariance structure with the best fit (smallest Akaike's value) was the unstructured (UN). Treatment means were computed with the LSMEANS option and significance was defined as $\mathrm{P}<0.05$.

\section{Results}

There was effect of treatment (TR, $\mathrm{P}=0.01)$ and significant interaction of TR $\times$ PR $(P=0.0054)$ for rumen weight after the finishing period (Table 2). In this period, crude glycerin treatments showed greater rumen weights when compared to control treatment (G0 vs G, $P=0.0110)$. A significant interaction of $T R \times P R(P=0.0399)$ was also observed for omasum weight after the finishing period. However, without significant contrasts for linear and quadratic effects of crude glycerin, as well as the contrast between G0 vs G (P > 0.05). Significant differences among feedlot periods were observed for all stomach compartments (rumen, reticulum, omasum and abomasum), with the highest weights observed for the animals slaughtered after the finishing period $(\mathrm{P}<0.05)$. The increasing inclusion of crude glycerin did not compromise the rumen and liver of the animals $(\mathrm{P}>0.05)$.

Significant differences among feedlot periods were observed for the number of papillae (NOP, $\mathrm{P}=0.02$ ) and mitotic index (MIT, $\mathrm{P}=0.01$ ), with the highest values observed for the finishing period (Table 2).

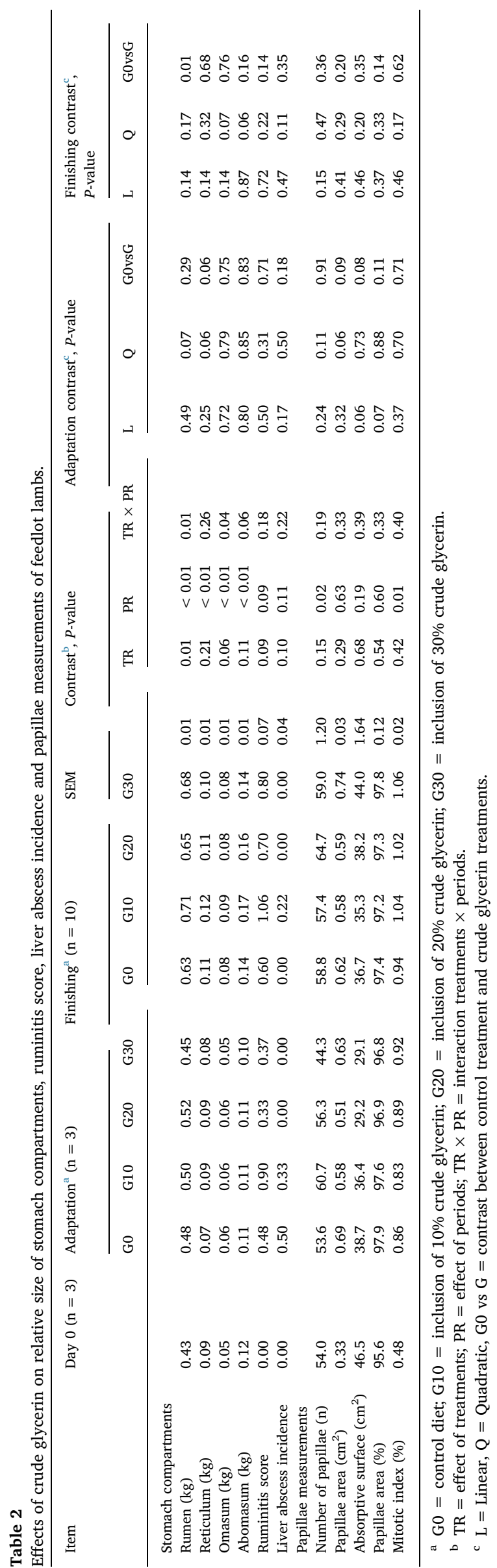




\section{Discussion}

The increasing body weight of the animals during feedlot reflected in greater weight of stomach compartments (rumen, reticulum, omasum and abomasum), thus justifying the observed difference among periods. However, the inclusion of crude glycerin resulted in larger rumen sizes in the finishing period, being $8 \%$ heavier compared with the control treatment (G0 vs G). Probably, the crude glycerin may have stimulated rumen growth due to its fermentative characteristic, mainly by increasing the total rumen VFA (Trabue et al., 2007) with greater molar concentrations of rumen propionate (van Cleef et al., 2015) and butyrate (San Vito et al., 2016). The presence of VFA in the ruminal lumen promotes the growth and proliferation of the papillae, with increased absorption area, improving the removal capacity of these acids as well as providing greater energy absorption for the animal (Sander et al., 1959; Costa et al., 2008; Gorka et al., 2009). However, as the effect of the crude glycerin inclusion on the area of papillae absorption was not observed, it is assumed that the greater weight of rumen may be due to the greater proliferation of the papillae, thus generating a greater rumen wall surface.

The mitotic index and number of papillae of the ruminal epithelium increased considerably during the finishing period when compared with day 0 and adaptation period. The greater mitotic index is indicative of cell proliferation and represents the cells in renewal cycle. This index can be stimulated by butyric (Sakata and Tamate, 1977a, b) and propionic acid (Sakata and Tamate, 1979), however the butyric acid is far more effective (Sutton et al., 1963; Kauffold et al., 1977). Because a portion of crude glycerin (25-45\%) is converted to propionate and butyrate in the rumen (Krehbiel, 2008; Omazic et al., 2015) and the propionate is a stimulator of insulin release in vivo (Sakata et al., 1980), it is possible that insulin could be a mediator in the stimulation of mitosis in the ruminal epithelium. According to Goodlad (1981), ruminal epithelial mitotic index has been shown to be stimulated by intravenous insulin infusions.

These results represent aspects of the adaptation physiological process and can indicate that adaptation was correctly conducted. However, the number of cells in the epithelium can also represent a disturb in the rates of cell division and turnover, causing pathological conditions such as hyperkeratosis, parakeratosis or ruminitis (Fell and Weekes, 1975). The weight of the rumen epithelium has a clear and major impact on the digestive capabilities and supply of substrates to the growing ruminant (Baldwin et al., 2004). Thus, considering that the rumen consists of a nonglandular mucosa and represents the fermentative chamber where most of the digestion happens by the joint action of the microorganisms, it can be assumed that the volumetric capacity of the rumen determines the quantity of feed intake and that the greater development of the muscular layer also can be associated to a greater necessity of ruminal motility (Membrive, 2016).

The VFA are the main products formed in the fermentative digestion and represents the greatest energy source for ruminants (50-70\%). In addition, the higher consumption may provide an increased number of microorganisms, being an important protein source for improved animal performance. Nevertheless, the VFA production is the main mechanism of ruminal $\mathrm{pH}$ reduction. When it drastically happens, and rumen epithelium is not fully developed to absorb these products, the consequence is the ruminal acidification. The ruminal acidosis usually occurs during the first weeks of feedlot, and it is due to abrupt changes in the diets with great impact in DMI and, in more severe cases, causes animal death (Nagaraja and Titgemeyer, 2007; McCann et al., 2016; Millen et al., 2016). As no clinical manifestations resulted from ruminal acidosis (such as laminitis, liver abscess, ruminitis and lesions in the ruminal mucosa) were observed, we concluded that all diets were effective in adapting the animals.

Although all treatments presented ruminitis after the beginning of the feedlot, the scores observed were very low considering the scale from 1 to 10 , not being able to compromise the performance of the animals. According to Owens et al. (1998), the high incidence of ruminitis can compromise the absorption of nutrients and consequently reduce animal performance. A little or no evidence of liver abscess observed in all periods indicates that there was no disorder started by acidosis, such as ruminitis. In addition, ruminal epithelium may be the first step in the development of future abscesses, and some ruminal microorganisms like Fusobacterium necrophorum can migrate through blood portal system and cause liver abscesses (Nagaraja and Chengappa, 1998; Millen et al., 2016). According to Owens et al. (1998), the high incidence of ruminitis can compromise the absorption of nutrients and consequently reduce animal performance.

The initial (day 0) and final data of stomach compartments show that changes among them were still happening. At the beginning of feedlot (d0), rumen and abomasum represented approximately $62.3 \%$ and $17.4 \%$ of stomach compartments, respectively, reaching $66.1 \%$ and $14.8 \%$ at the end of finishing period. According to Membrive (2016), the rumen epithelium reaches the complete development at approximately 2-3 months of age, and it determines the absorption capacity of the rumen. Thus, a better initial stimulus for increased rumen and papillae growth would reflect in higher ingestion capacity and higher animal performance. A greater DMI and passage of substrates may have stimulated the growth of omasum, justifying the higher weight in the finishing period of the feedlot.

\section{Conclusions}

The increasing inclusion of up to $30 \%$ of crude glycerin $/ \mathrm{kg}$ DM in diets for crossbred lambs did not compromise the stomach compartments, and rumen papillae measurements in both periods of the feedlot. As no clinical manifestations resulted from ruminal acidosis, such as liver abscess, ruminitis, and lesions in the ruminal mucosa were observed in any of periods and treatments studied, we concluded that the replacement of corn cracked grain by crude glycerin (up to $30 \% \mathrm{DM}$ ) were effective in the animals' adaptation to concentrate-based diets.

\section{Conflict of interest}

The authors declare no known conflict of interest.

\section{Acknowledgment}

The authorsthank São Paulo Research Foundation (FAPESP) for the scholarships (grant\# 2015/04595-4 and grant\# 2013/18118-8), and Caramuru Alimentos SA.

\section{References}

Almeida, M.T.C., Ezequiel, J.M.B., Paschoaloto, J.R., Perez, H.L., de Carvalho, V.B., Castro Filho, E.S., van Cleef, E.H.C.B., 2017. Effects of high concentrations of crude glycerin in diets for feedlot lambs: feeding behaviour, growth performance, carcass and non-carcass traits. Anim. Prod. Sci. https://doi.org/10.1071/AN16628.

AOAC, 1990. Official Methods of Analysis, 15th ed. Association of Official Analytical Chemists Inc., Arlington, VA, USA.

Baldwin, R., McLeod, K., Klotz, J., Heitmann, R., 2004. Rumen development, intestinal growth and hepatic metabolism in the pre-and postweaning ruminant. J. Dairy Sci. 87, E55-E65.

Bigham, M.L., McManus, W.R., 1975. Whole wheat grain feeding of lambs. V. Effects of roughage and wheat grain mixtures. Aust. J. Agric. Resour. Econ. 26, 1053-1062.

Brink, D.R., Lowry, S.R., Stock, R.A., Parrott, J.C., 1990. Severity of liver-abscesses and efficiency of feed-utilization of feedlot cattle. J. Anim. Sci. 68, 1201-1207.

Brown, M.S., Ponce, C.H., Pulikanti, R., 2006. Adaptation of beef cattle to high-concentrate diets: performance and ruminal metabolism. J. Anim. Sci. 84, E25-33.

Costa, S.F., Pereira, M.N., Melo, L.Q., Resende, J.C., Chaves, M.L., 2008. Lactate, propionate and, butyrate induced morphological alterations on calf ruminal mucosa and epidermis - I Histologycals aspects. Arq. Bras. Med. Vet. Zool. 60, 1-9.

Daniel, J.L.P., Resende Júnior, J.C., Cruz, F.J., 2006. Participation of the reticulorumen and omasum in the total absorptive surface of the bovine forestomach. Braz. J. Vet. Res. Anim. Sci. 43, 688-694.

Dirksen, G., 1985. The rumen acidosis complex-recent knowledge and experiences (1). A review. Tierarztl. Prax. 13, 501-512.

Ezequiel, J.M.B., Sancanari, J.B.D., Neto, O.R.M., da Silva, Z.F., Almeida, M.T.C., Silva, 
D.A.V., van Cleef, F.O.S., van Cleef, E.H.C.B., 2015. Effects of high concentrations of dietary crude glycerin on dairy cow productivity and milk quality. J. Dairy Sci. 98, 8009-8017.

Favaro, V.R., Ezequiel, J.M.B., D’Aurea, A.P., van Cleef, E.H.C.B., Sancanari, J.B.D., Santos, V., Homem, A.C., 2015. Glycerin in cattle feed: intake, digestibility, and ruminal and blood parameters. Semin-Cienc. Agrar. 36, 1495-1505.

FDA, 2006. Food Drug Administration Code of Federal Regulations, 21CFR582.1320. Good Lab. Pract. 21, 306-319.

Fell, B., Weekes, T., 1975. Food intake as a mediator of adaptation in the ruminal epithelium. Digest. Metabol. Rumin. 101-118.

Galfi, P., Neogrady, S., Sakata, T., 1991. Effects of Volatile Fatty Acids on the Epithelial Cell Proliferation of the Digestive Tract and Its Hormonal mediation-3.

Goodlad, R.A., 1981. Some effects of diet on the mitotic index and the cell cycle of the ruminal epithelium of sheep. Q. J. Exp. Physiol. 66, 487-499.

Gorka, P., Kowalski, Z.M., Pietrzak, P., Kotunia, A., Kiljanczyk, R., Flaga, J., Holst, J.J., Guilloteau, P., Zabielski, R., 2009. Effect of sodium butyrate supplementation in milk replacer and starter diet on rumen development in calves. J. Physiol. Pharmacol. 60 (Suppl 3), 47-53.

Hendrix, D.L., 1993. Rapid extraction and analyses of nonstructural carbohydrates in plant tissues. Crop Sci. 33, 1306-1311.

Kauffold, P., Voigt, J., Herrendorfer, G., 1977. The effect of nutritional factors on the ruminal mucosa. 3. Condition of the mucosa after infusion of propionic acid, acetic acid and butyric acid. Arch. Tierernahr. 27, 201-211.

Kern, R., Lindholm-Perry, A., Freetly, H., Kuehn, L., Rule, D., Ludden, P., 2016. Rumen papillae morphology of beef steers relative to gain and feed intake and the association of volatile fatty acids with kallikrein gene expression. Livest. Sci. 187, 24-30.

Krehbiel, C., 2008. Ruminal and physiological metabolism of glycerin. J. Anim. Sci. 86 ESuppl. 2/J 392.

McCann, J.C., Luan, S., Cardoso, F.C., Derakhshani, H., Khafipour, E., Loor, J.J., 2016. Induction of subacute ruminal acidosis affects the ruminal microbiome and epithelium. Front. Microbiol. 7, 701.

Membrive, C.M.B., 2016. Anatomy and physiology of the Rumen. In: Millen, D.D., Arrigoni, M.D.B., Pacheco, R.D.L. (Eds.), Rumenology. Springer Nature, Switzerland, pp. 1-38.

Millen, D.D., Pacheco, R.D.L., da Silva Cabral, L., Cursino, L.L., Watanabe, D.H.M., Rigueiro, A.L.N., 2016. Ruminal Acidosis. In: Millen, D.D., Arrigoni, M.D.B., Pacheco, R.D.L. (Eds.), Rumenology. Springer Nature, Switzerland, pp. 127-156.

Missio, R.L., Brondani, I.L., Alves, D.C., da Silveira, M.F., Freitas, L.D., Restle, J., 2010 Ingestive behavior of feedlot finished young bulls fed different concentrate levels in the diet. Rev Bras Zootecn 39, 1571-1578.

Nagaraja, T.G., Chengappa, M.M., 1998. Liver abscesses in feedlot cattle: a review. J. Anim. Sci. 76, 287-298.
Nagaraja, T.G., Titgemeyer, E.C., 2007. Ruminal acidosis in beef cattle: the current microbiological and nutritional outlook. J. Dairy Sci. 90 (Suppl 1), E17-38.

NRC, 2007. Nutrient Requeriments of Small Ruminants: Sheep, Goats, Cervids, and New World Camelids. The National Academies Press, Washington, DC, pp. 408.

Omazic, A.W., Kronqvist, C., Zhongyan, L., Martens, H., Holtenius, K., 2015. The fate of glycerol entering the rumen of dairy cows and sheep. J. Anim. Physiol. Anim. Nutr. (Berl) 99, 258-264.

Owens, F.N., Secrist, D.S., Hill, W.J., Gill, D.R., 1998. Acidosis in cattle: a review. J. Anim. Sci. 76, 275-286.

Polizel, D.M., Gentil, R.S., Ferreira, E.M., Souza, R.A., Freire, A.P.A., Faleiro Neto, J.A., Pires, A.V., Susin, I., 2013. Rumen metabolism in lambs fed high-concentrate diets containing increasing levels of crude glycerin. J. Anim. Sci. 91 (Suppl. 2), 96.

Resende Junior, J.C., Alonso, L.S., Pereira, M.N., Magallanes, M.G.R., Duboc, M.V. Oliveira, E.C., Melo, L.Q., 2006. Effect of the feeding pattern on rumen wall morphology of cows and sheep. Braz. J. Vet. Res. Anim. Sci. 43, 526-536.

Sakata, T., Tamate, H., 1977a. Effect of intraruminal injection of n-sodium butyrate on the mitotic indices in sheep ruminal epithelium. Tohoku J. Agric. Res. 27, 133-135.

Sakata, T., Tamate, H., 1977b. Effect of n-butyrate administration rate on the epithelial cell proliferation in adult sheep rumen: a preliminary report. Tohoku J. Agric. Res. 27, 136-138.

Sakata, T., Tamate, H., 1979. Rumen epithelium cell proliferation accelerated by propionate and acetate. J. Dairy Sci. 62, 49-52.

Sakata, T., Hikosaka, K., Shiomura, Y., Tamate, H., 1980. Stimulatory effect of insulin on ruminal epithelium cell mitosis in adult sheep. Br. J. Nutr. 44, 325-331.

San Vito, E., Lage, J., Messana, J., Dallantonia, E., Frighetto, R., Reis, R., Neto, A., Berchielli, T., 2016. Performance and methane emissions of grazing Nellore bulls supplemented with crude glycerin. J. Anim. Sci. 94, 4728-4737.

Sander, E.G., Warner, R.G., Harrison, H.N., Loosli, J.K., 1959. The stimulatory effect of sodium butyrate and sodium propionate on the development of rumen mucosa in the young calf. J. Dairy Sci. 42, 1600-1605.

Stobo, I.J., Roy, J.H., Gaston, H.J., 1966. Rumen development in the calf. 2. The effect of diets containing different proportions of concentrates to hay on digestive efficiency. Br. J. Nutr. 20, 189-215.

Sutton, J.D., Mcgilliard, A.D., Jacobson, N.L., 1963. Functional development of rumen mucosa.1. Absorptive Ability. J. Dairy Sci. 46, 426.

Trabue, S., Scoggin, K., Tjandrakusuma, S., Rasmussen, M.A., Reilly, P.J., 2007. Ruminal fermentation of propylene glycol and glycerol. J. Agric. Food Chem. 55, 7043-7051.

van Cleef, E.H.C.B., Almeida, M.T.C., Perez, H.L., van Cleef, F.O.S., Silva, D.A.V., Ezequiel, J.M.B., 2015. Crude glycerin changes ruminal parameters, in vitro greenhouse gas profile, and bacterial fractions of beef cattle. Livest. Sci. 178, 158-164.

Van Soest, P.J., Wine, R.H., 1967. Use of detergents in analysis of fibrous feeds. IV. Determination of plant cell-wall constituents. J. Assoc. Off Anal. Chem. 50, 50-55. 